Tropical Journal of Pharmaceutical Research, June 2004; 3 (1): 305-309

(C) Pharmacotherapy Group,

Faculty of Pharmacy, University of Benin,

Benin City, Nigeria

All rights reserved.

Available online at http://www.tjpr.freehosting.net

Opinion Article

\title{
Effect of chronic administration of Boerhaavia diffusa Linn. leaf extract on experimental diabetes in rats
}

\author{
Rao K. Nalamolu ${ }^{1}$, Krishna M. Boini ${ }^{2,3}$, Srinivas Nammi ${ }^{2,3 \Phi}$ \\ ${ }^{1}$ Pharmacology Division, GITAM Dental College, Visakhapatnam, Andhra Pradesh, India \\ ${ }^{2}$ Pharmacology Division, Andhra University, Department of Pharmaceutical Sciences, Visakhapatnam, Andhra \\ Pradesh, India \\ ${ }^{3}$ Department of Physiology, University of Tübingen, D 72076 Tübingen, Germany
}

\begin{abstract}
Purpose: The root and aerial parts of Boerhaavia diffusa Linn. (Nyctaginaceae) were used in Ayurveda for the treatment of diabetes. The present study is aimed at evaluating the antidiabetic activity of chloroform extract of Boerhaavia diffusa leaves on chronic administration in streptozotocin-induced non-insulin-dependent diabetes mellitus (NIDDM) model diabetic rats.

Methods: The blood glucose lowering activity of the leaf extract was studied in streptozotocininduced (65 mg/kg, i.v.) NIDDM model diabetic rats after oral administration of the extract at daily doses of 50, 100 and $200 \mathrm{mg} / \mathrm{kg}$ body weight for four weeks and compared with glibenclamide. Blood samples were collected from the tail vein before and also at weekly intervals for four weeks from the first dose of drug administration and blood glucose was analyzed by glucose-oxidase method using a visible spectrophotometer.

Results: The leaf extract of $B$. diffusa produced dose-dependent reduction in blood glucose in streptozotocin-induced NIDDM rats comparable to that of glibenclamide. The results indicate that the reduction in blood glucose produced by the extract is probably through rejuvenation of pancreatic $\beta$-cells or through extrapancreatic action.

Conclusion: The chloroform extract of Boerhaavia diffusa has significant antidiabetic activity and this supports the traditional usage of the plant by Ayurvedic physicians for the control of diabetes.

Key words: Blood glucose, Boerhaavia diffusa, Diabetes mellitus Streptozotocin, Rats

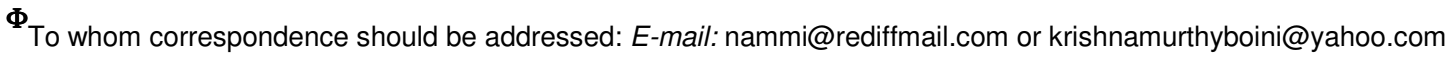




\section{Introduction}

Diabetes mellitus, an endocrine disorder, is characterized by hyperglycemia and affects a large number of people worldwide. By the year 2010, the total number of people worldwide with diabetes is projected to reach 239 millions ${ }^{1}$. In modern medicine, no satisfactory effective therapy is still available to cure diabetes mellitus ${ }^{2}$. Currently available therapeutic options such as dietary modification, oral hypoglycemics and insulin have limitations of their own in treating noninsulin dependent diabetes mellitus $(\text { NIDDM })^{3-4}$. Therefore, the search for more effective and safer hypoglycemic agents has continued to be an area of active research. The World Health Organization has recommended the evaluation of the effectiveness of medicinal plants in condition where the conventional allopathic treatment of diabetes is not adequate ${ }^{5-6}$.

In the indigenous Indian system of medicine (Ayurveda), many herbal medicines have been recommended for the treatment of diabetes or 'madhumeha' and some of them have been experimentally evaluated. Boerhaavia diffusa Linn. (Nyctaginaceae) is a small perennial creeping herb, commonly known as "Red hogweed" and distributed widely all over in India, and in many other countries. The root and the whole plant are used as an Ayurvedic medicine in India and Unani medicine in Arab countries for the treatment of diabetes, stress, dyspepsia, abdominal pain, inflammation, jaundice, enlargement of spleen, congestive heart failure and bacterial infections ${ }^{-11}$. The plant is known to possess anti-inflammatory ${ }^{12-13}$, anticonvulsant ${ }^{14}$, antifibrinolytic ${ }^{15}$, diuretic ${ }^{16}$, hepatoprotective ${ }^{17-20}$ and immunomodulatory ${ }^{21-22}$ activities. It has also been reported to be useful in the treatment of elephantiasis, night blindness, corneal ulcers and nephritic syndrome ${ }^{23-26}$.

Recently, the aqueous leaf extract of the plant has been studied for its antidiabetic effect in alloxan-induced diabetic rats ${ }^{27-28}$. The present investigation is aimed at evaluating the antidiabetic activity of the chloroform extract of the plant leaves on chronic treatment of streptozotocin-induced NIDDM model diabetic rats.

\section{Experimental}

\section{Chemicals}

Glibenclamide was a generous gift sample from Hoechst Pharmaceuticals, Mumbai, India. Glucose assay kit was obtained from the Diagnostic Division of Dr. Reddy's Laboratories, Hyderabad, while streptozotocin was purchased from SigmaAldrich, St. Louis, USA.

\section{Plant Material and Extraction}

Fresh leaves of $B$. diffusa were purchased from local traders in Visakhapatnam, India and shade dried for about two weeks. The leaves were botanically authenticated and a voucher specimen has been preserved for future reference. The dry leaf powder $(3 \mathrm{~kg})$ was extracted with chloroform in Soxhlet apparatus for $24 \mathrm{hr}$ and the extract was evaporated to dryness under vacuum in a vacuum desiccator $(268 \mathrm{~g})$.

\section{Animals}

Adult male Sprague-Dawley rats (National Institute of Nutrition, Hyderabad) weighing 250-300 g were used in the study. They were divided into 6 groups of six each and were provided with standard pellet diet (Ratan Brothers, Hyderabad) and water ad libitum. All rats were acclimatized to the laboratory conditions for at least 10 days prior to the experiment and were maintained in a well-ventilated animal house with 12-hr light and dark cycle. As appropriate, the animals were fed with the standard pellet diet throughout the experiment, except for $12 \mathrm{hr}$ prior to blood collection when only water was given. 
Odeniyi \& Jaiyeoba., 2004

The experimental protocol was been approved by the Institutional Animal Ethics Committee and by the animal regulatory body of the India government (Regd. No. 516/01/A/CPCSEA).

The rats assigned to groups I to $\mathrm{V}$ were rendered diabetic by injecting streptozotocin $(65 \mathrm{mg} / \mathrm{kg}$, i.v.; dissolved in $0.1 \mathrm{M}$ citrate buffer; $\mathrm{pH}$ 4.5) after a baseline blood glucose estimation was done. After 2 to 3 days, the condition of diabetes was assessed by periodic examination of blood glucose using glucose-assay sticks. Only animals with stable blood glucose above $300 \mathrm{mg} / \mathrm{dl}$ were selected for the study.

B. diffusa extract, in the form of a suspension in $0.1 \%$ sodium CMC at daily doses of 50,100 and $200 \mathrm{mg} / \mathrm{kg}$ body weight, were administered orally to the rats in groups I, II \& III, respectively for 4 weeks. Rats in group IV received a similar treatment with glibenclamide $(25 \mu \mathrm{g} / \mathrm{kg})$ daily for 4 weeks while the rats in groups $\mathrm{V}$ and $\mathrm{VI}$ received $3 \mathrm{ml}$ of $0.1 \%$ sodium carboxymethylcellulose and were used as diabetic and normal controls, respectively.

\section{Collection of Blood and Analytical Procedure}

Blood samples were collected before and also at weekly intervals for 4 weeks from the from the tail vein of the rats from the first
Release properties of suppositories

dose of drug administration. GlucoseOxidase assay method ${ }^{29-30}$ was used to determine the blood glucose.

\section{Data and Statistical Analysis}

Data are expressed as means \pm standard error of means of at least triplicate determinations. Statistical analysis was carried out using one-way analysis of variance (ANOVA) and Dunnett's $t$-test. At $95 \%$ confidence interval $p$ values less than 0.05 were considered to be significant.

\section{Results and Discussion}

The present study was conducted to study the antidiabetic activity of $B$. diffusa in rats to provide scientific evidence for its traditional usage in the control of diabetes. From the results obtained, it is obvious that chronic administration of $B$. diffusa extract to streptozotocin-induced NIDDM rats produced blood glucose reduction in a dosedependent manner. To determine whether there was a statistically significant difference in hypoglycemia achieved by the three doses (50, 100 and $200 \mathrm{mg} / \mathrm{kg}$, p.o.) chronically administered, the data were compared by using one-way analysis of variance and the individual groups were compared with control group using Dunnet's $t$-test. The extract of $B$. diffusa produced a significant reduction in blood glucose after 1

Table 1: Percentage blood glucose reduction produced by $B$. diffusa after chronic oral administration in streptozotocin-induced NIDDM model rats

\begin{tabular}{|c|c|c|c|c|}
\hline \multirow[b]{2}{*}{ Rats } & \multicolumn{4}{|c|}{ Percent Blood Glucose Reduction $(n=6)$} \\
\hline & Week 1 & Week 2 & Week 3 & Week 4 \\
\hline Normal Control & $-9.65 \pm 1.20$ & $4.05 \pm 0.84$ & $7.58 \pm 2.59$ & $-4.36 \pm 1.64$ \\
\hline Diabetic Control & $-10.35 \pm 9.81$ & $-15.31 \pm 16.58$ & $-18.93 \pm 10.02$ & $-20.33 \pm 19.35$ \\
\hline Treated with $50 \mathrm{mg} / \mathrm{kg}$ of extract & $4.34 \pm 2.43$ & $9.56 \pm 4.66$ & $13.82 \pm 8.57^{*}$ & $16.30 \pm 4.56$ \\
\hline Treated with $100 \mathrm{mg} / \mathrm{kg}$ of extract & $10.32 \pm 8.08^{*}$ & $18.60 \pm 9.89^{*}$ & $24.51 \pm 8.24^{\star \star *}$ & $29.98 \pm 6.94^{*}$ \\
\hline Treated with $200 \mathrm{mg} / \mathrm{kg}$ of extract & $25.37 \pm 10.50^{*}$ & $28.32 \pm 8.68^{* *}$ & $33.04 \pm 7.13^{\star * *}$ & $38.63 \pm 9.46^{\star *}$ \\
\hline $\begin{array}{l}\text { Treated with } 25 \mu \mathrm{g} / \mathrm{kg} \\
\text { glibenclamide }\end{array}$ & $66.20 \pm 9.58^{* * *}$ & $60.60 \pm 7.93^{* * *}$ & $65.74 \pm 8.22^{\star \star *}$ & $59.01 \pm 9.89^{\star \star *}$ \\
\hline
\end{tabular}




\section{Odeniyi \& Jaiyeoba., 2004}

week of treatment and increased furthermore at the end of $4^{\text {th }}$ week by $30 \%$ $(p<0.01)$ and $38.6 \% \quad(p<0.001)$ at doses of 100 and $200 \mathrm{mg} / \mathrm{kg}$ body weight, respectively although the lowest dose (50 $\mathrm{mg} / \mathrm{kg}$ ) tested could produced significant change only after 3 weeks of treatment (Table 1). Glibenclamide (25 $\mu \mathrm{g} / \mathrm{kg}$, administered orally, p.o.) produced a significant reduction $(p<001)$ compared to diabetic control at the end of $1^{\text {st }}$ week $(66.2 \%)$. The results obtained in this study are in good agreement with those observed by previous investigators in alloxan-induced diabetic rats ${ }^{27-28}$.

Streptozotocin, a betacytotoxin induces a "chemical diabetes" in a wide variety of animal species through a massive destruction of $\beta$-cells of the islets of Langerhans and resulting in reduced synthesis and release of insulin ${ }^{32}$. It is well established that sulphonylureas produce hypoglycemia by increasing the secretion of insulin from pancreas and by increasing the glycogen deposition in the liver ${ }^{33,34}$. These compounds are active in mild streptozotocininduced diabetes whereas they are inactive in intense streptozotocin diabetes (nearly all $\beta$-cells have been destroyed). Since our results showed that glibenclamide reduced blood glucose levels in hyperglycemic animals, the state of diabetes is not severe $^{35,36}$. Streptozotocin-treated animals receiving the leaf extract of $B$. diffusa showed rapid normalization of blood glucose levels in comparison to control and this could be due to the possibility that some $\beta$ cells were still active and were acted upon by $B$. diffusa to exert their insulin releasing effect. This suggests that the mode of action of the active ingredients of $B$. diffusa is probably mediated by an enhanced secretion of insulin, like sulphonylureas. Earlier investigations ${ }^{27-28}$ also revealed an insulin releasing mechanism by the aqueous leaf extract of $B$. diffusa and lend support for the results observed in this study. However, the possibility of enhanced tissue glucose utilization by $B$. diffusa cannot be ruled out.
Release properties of suppositories

Further work on fractionation, purification, identification of active principle(s) and detailed mechanistic evaluation on the leaves of $B$. diffusa is yet to be carried out.

\section{References}

1. American Diabetes Association. Clinical practice recommendations. Diabetes Care 1997; 20: S1-S70.

2. Sumana G, Suryawashi SA. Effect of Vinca rosea extracts in treatments of alloxan diabetes in male albino rats. Ind J Expt Biol 2001; 39: 748 $-758$.

3. Berger S. Incidence of severe side effects during therapy with sulphonylurea and biguanides. Hormone Metab Res 1985; 17: 111-115.

4. Hupponen R. Adverse cardiovascular effects of sulphonylurea drugs: Clinical significance. Med Toxicol 1978; 2: 190-209.

5. WHO Expert committee on diabetes mellitus. Second report. Technical report series World Health Organization, Geneva, 1980, 646.

6. Upathaya V, Pandy K. Ayurvedic approach to diabetes mellitus and its management by indigenous resources. In: Bajaj JS (ed.), Diabetes mellitus in developing countries, New Delhi, Interprint, 1984, 375-377.

7. Nadkarni, KM. Boerhaavia diffusa. Indian Materia Medica, ed 3, Mumbai, Popular Book Depot, 1954, 202-207.

8. Kirtikar KR, Basu, BD. Boerhaavia diffusa. Indian Medicinal Plants, ed 2, Allahabad, Lalit Mohan Basu Publications, 1933, 1052-1054.

9. Chopra RW, Chopra IC, Handa KL, Kapur LD. Medicinal plants in diabetes. In: P.Gupta (ed), Indiginous Drugs of India, ed 2, Calcutta, India, Dhar and Sons Ltd, 1958, 314-316.

10. Chopra RN, Nayar SL, Chopra IC. Glossary of Indian Medicinal Plants. New Delhi, National Institutes of Science Communication, 1996.

11. Aslam M. Asian medicine and its practise in Britain. In: Evans, WC (ed.). Pharmacognosy, London, UK, Saunders Company Ltd, 1996, 499-500.

12. Bhalla TN, Gupta MB, Bhargava KP. Antiinflammatory activity of Boerhaavia diffusa. $J$ Res Ind Med 1971; 6: 11-15.

13. Hiruma-Lima CA,. Gracioso JS, Bighetti EJ, Germonsen RL, Souja BAR. The juice of fresh leaves of Boerhaavia diffusa L.(Nyctaginaceae) markedly reduces pain in mice. J Ethnopharmacol 2000; 71: 267-274.

14. Mudgal V. Studies on medicinal properties of Convolvulus pluricaulis and Boerhaavia diffusa. Planta Med 1975; 28: 62-68. 


\section{Odeniyi \& Jaiyeoba., 2004}

15. Jain GK, Khanna NM. Punarnavoside: a new antifibrolytic agent from Boerhaavia diffusa L. Ind J Chem 1989; 28: 163-166.

16. Singh RP, Shokala KP, Pandey BL, Singh, RG, Usha, Singh R. Recent approach in clinical and experimental evaluation of diuretic action of Purnarnava (Boerhaavia diffusa) with special effect to nephrotic syndrome. $J$ Ind Med Res 1992; 11: 29-36.

17. Chakraborty KK, Handa SS. Antihepatotoxic investigations of Boerhaavia diffusa $L$. Ind Drugs 1989; 27: 161-166.

18. Chandan BK, Sharma AK, Anand KK. Boerhaavia diffusa: a study of its hepatoprotective activity. J Ethnopharmacol 1991; 31: 299-307.

19. Rajukumari G, Sarla A, Agarwal SS. Hepatoprotective activity of Boerhaavia diffusa Linn. against country made liquor induced hepatotoxicity in albino rats fed on controlled calorie diet. Ind J Pharmacol 1991; 23: 264267.

20. Rawat AKS, Mehrotra S, Tripathi SC, Shome U. Hepatoprotective activity of Boerhaavia diffusa L. roots - a popular Indian ethnomedicine. $J$ Ethnopharmacol 1997; 56: 61-66.

21. Mehrotra S, Mishra KP, Maurya R, Srimal RC, Singh VK. Immunomodulation by ethanolic extract of Boerhaavia diffusa roots. Int Immunopharmacol 2002; 2: 987-996.

22. Mehrotra S, Singh VK, Agarwal SS, Maurya R, Srimal,R.C. Antilymphoproliferative activity of ethanolic extract of Boerhaavia diffusa roots. Exptl Mol Pathol 2002; 72: 236-242.

23. Mishra J, Singh R. The effect of indigenous drug Boerhaavia diffusa on kidney regeneration. Ind $J$ Pharmacol 1980; 12: 59-64.

24. Singh $\mathrm{RH}$, Udupa $\mathrm{KN}$. Studies on the Indian indigenous drug Punarnava (Boerhaavia diffusa L.) Part I, Identification and pharmacological studies. J Res Ind Med 1972; 7: 1-12.

25. Singh $\mathrm{RH}$, Udupa $\mathrm{KN}$. Studies on the Indian indigenous drug Punarnava (Boerhaavia diffusa L.) Part III. Experimental and pharmacological studies. J Res Ind Med 1972; 7: $17-27$.
Release properties of suppositories

26. Singh $\mathrm{RH}$, Udupa $\mathrm{KN}$. Studies on the Indian indigenous drug Punarnava (Boerhaavia diffusa L.) Part IV. Preliminary controlled clinical trial in nephrotic syndrome. $J$ Res Ind Med 1972; 7: 28-33.

27. Chude MA, Orisakwe OJ, Afonne OJ, Gamaniel $\mathrm{KS}$, Vongtau $\mathrm{OH}$, Obi E. Hypoglycemic effect of the aqueous extract of Boerhaavia diffusa leaves. Ind J Pharmacol 2001, 33: 215-216.

28. Pari L, Satheesh MA. Antidiabetic activity of Boerhaavia diffusa L.: Effect on hepatic key enzymes in experimental diabetes. $J$ Ethnopharmacol 2004; 91: 109-113.

29. Trinder $P$. Determination of blood glucose using an oxidase-peroxidase system with a noncarcinogenic chromogen. J Clin Pathol 1969; 22: 485-520.

30. Glynn JP, Kendal SE. In: Varley H, Gowenlock $\mathrm{AH}$, Bell M (eds.), Practical Clinical Biochemistry $5^{\text {th }}$ edition, CBS Publishers, New Delhi, Vol I: 1991 389-391.

31. Baily CJ, Flatt, PR. Antidiabetic drugs, new developments. Ind Biotechnol 1986; 6:139 142.

32. Rerup CC. Drugs producing diabetes through damage of insulin secreting cells. Pharmacol Rev 1970; 22: 485 - 520.

33. Grodsky GM, Epstein GH, Fanska R, Karam, JH. Pancreatic action of sulphonylureas. Fed Proc 1971; 36: 2719 - 2728.

34. Yallow RS, Black $H$, Villazan M, Berson SA. Comparison of plasma insulin levels following administration of tolbutamide and glucose. Diabetes 1960; 9: 356 - 362.

35. Krall LP, Chabot VA. Oral hypoglycemic agent update. Med Clin North Am 1978; 62: 681-694.

36. Grunberger G, Ryan J, Gorden P. Sulfonylureas do not affect insulin binding or glycemic control in insulin-dependent diabetics.Diabetes 1982; 31: 890-896.;43(9):624-7. 